\title{
A repurposing framework for alignment of regional development and mine closure
}

\author{
DP Murphy Golder Associates Pty Ltd, Australia \\ J Fromm Pilbara Development Commission, Australia \\ R Bairstow Pilbara Development Commission, Australia \\ D Meunier Jacobs Australia, Australia
}

\begin{abstract}
In response to the challenges of population growth and associated economic sustainability, Australian governments are moving towards more structured and coordinated approaches to regional development. The Pilbara Regional Investment Blueprint (Pilbara Blueprint), developed by the Pilbara Development Commission (Commission), establishes a vision for the region that seeks diverse, innovative and resilient commercial opportunities that are underpinned by capability development, investment capture and fostering growth, as well as maintaining a strong resources and energy industry. Key challenges for the achievement of this vision include complex planning and regulatory processes, as well as competition for productive land.

Concurrently, the modern Australian mining and energy industry is nearing maturity, with an increasing number of operations approaching closure and providing opportunity for the consideration of repurposing mined land and associated assets for productive economic use. Although good examples of mine repurposing exist at both the global and national levels, current mine closure planning practices within both government and industry do not readily support or encourage repurposing as a beneficial outcome.

The Commission has therefore engaged with government and industry stakeholders to develop a framework that aligns the objectives of minimising post-closure mining liability and achieving sustainable regional development, and that presents a unique opportunity to shift the current mine closure paradigm. Specifically, the Commission is building from existing land access and tenure frameworks to enhance existing transformational opportunities within the Pilbara, including renewable power generation, irrigated agriculture and tourism. This paper presents the proposed repurposing framework and discusses the process of stakeholder engagement, ongoing challenges to implementation and opportunities for proof of concept.
\end{abstract}

Keywords: relinquishment, repurposing, Pilbara Blueprint, regional development, Pilbara

\section{Introduction}

Government and the mining sector alike are faced with the complex and challenging objectives of sustainable development and regulation. Both seek certainty of development to support social and economic progress, financial return to taxpayers and shareholders, minimisation of costs, and intergenerational equity.

In response to the challenges of population growth and economic sustainability, federal, state and local governments within Australia, through the Regional Development Australia (RDA) initiative, are moving towards more structured and coordinated approaches to regional development (https://rda.gov.au). This includes drawing on the ability of communities to grow using human capital and innovative capacity (Tomaney 2010) and to seek economic diversity through attracting investment while managing conflicting values and priorities. In a review of these strategies, the Australian Bureau of Statistics (2013) contends that these commonly respond to, and address, the following issues:

- Diversification of industry base and associated skills to support diversification. 
- Population growth and demographic change.

- Supply of infrastructure for key services such as transport, water, power and communication.

- Conservation and environmental impact management.

While many regions within Australia remain dependent on resource development as their economic base, the objectives of mining companies are rarely aligned with the objectives for growth and diversification across non-mining industries and markets. Central to this is the issue of land access and the management of land use. Specifically, competition for productive land has become a key friction point for industry and government, as well as between industry sectors (Lock the Gate 2016a, 2016b; Roche \& Judd 2016).

However, the Australian mining industry is approaching maturity with several major mines entering the closure phase. Furthermore, the veracity of mine closure outcomes, including transparency of costs, has become a topic of public concern (Lock the Gate 2016a, 2016b; Roche \& Judd 2016). Many stakeholders are now questioning the ability of the mining industry to deliver on its rehabilitation commitment and are expressing concern regarding the potential growth in the legacy mine estate (Commonwealth of Australia 2019).

There are, however, examples of successful and sustainable achievement of alternative post-mining land use through commercial approaches to mine closure (i.e. repurposing) that take advantage of ongoing human and economic occupation (Harvey 2016; Pearman 2009).

In recognition of the opportunities presented by repurposing, the Pilbara Development Commission (Commission) has established the Mines and Infrastructure Repurposing Initiative (MIRI) in a non-commercial partnership with Golder Associates and Jacobs Australia. The MIRI has sought to engage with government and industry stakeholders to raise awareness of repurposing as an opportunity, to identify key constraints and challenges that must be addressed and to define a framework under which repurposing can be facilitated.

This paper explores the potential to align the objectives of minimising post-closure mining liability and achieving sustainable regional development within the Pilbara region. Specifically, a land tenure pathway for mine repurposing (LTPMR) is proposed for Western Australia, in which collaboration between industry and government has the potential to shift the current mine closure paradigm and deliver lasting economic, social and environmental value to the State.

\section{A vision for the Pilbara}

Within Western Australia, the Department of Primary Industries and Regional Development (DPIRD), through the Regional Development Council (RDC) and the Regional Development Commissions, is responsible for the effective planning, coordination and delivery of the State's regional development agenda. In parallel, the Department of Planning, Lands and Heritage (DPLH) manages and regulates key activities relating to land use planning, the land supply chain, and land administration; while the Department of Jobs, Tourism, Science and Innovation (JTSI) supports economic development across the State through the facilitation of significant industry investment in large and complex projects (i.e. state agreements), international trade and tourism.

The Pilbara Regional Investment Blueprint (Pilbara Blueprint) (Pilbara Development Commission 2015) establishes a vision for regional development that features diverse, innovative and resilient commercial opportunities that are underpinned by a strong resources and energy industry. The Pilbara Blueprint seeks to develop a strong regional economy through capability development, investment capture and growth development around nine pillars (Figure 1). Economic challenges faced by the Pilbara Blueprint include a reliance on the resource industry, the distance from capital cities, high-cost structures and a lack of critical mass in services. Geographic dispersion, community service availability and income inequality also present challenges to the strategy.

To meet the objectives of the Pilbara Blueprint, the Commission seeks to develop and implement transformational opportunities based on consideration of regional characteristics within the context of current and emerging mega trends. 
Effectively, the Pilbara Blueprint provides a framework to establish long-term economic diversity and enhanced livability to support expected population growth. While still supporting growth within the mining industry, the Pilbara Blueprint identifies the following opportunities to broaden the economic base of the region:

- High-value agriculture and cropping.

- Aquaculture, algae biofuels and co-products.

- Energy production and export.

- Nature-based tourism.

- Heritage- and Aboriginal-based tourism.

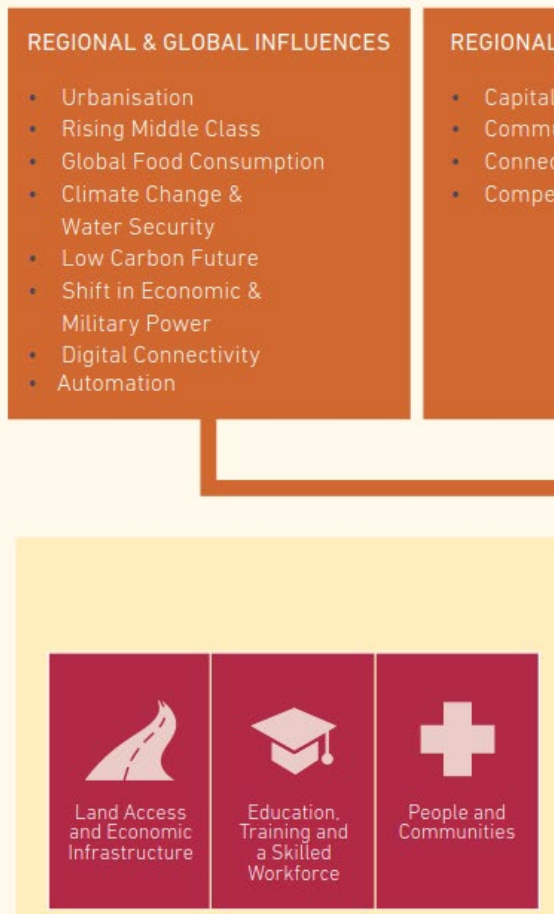

ENABLING

\section{REGIONAL PILLARS}

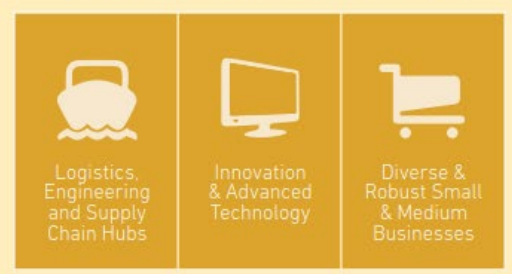

VALUE-ADDING

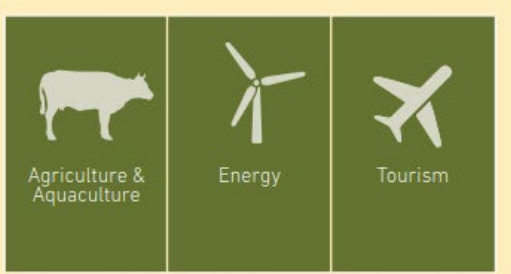

DIVERSIFYING

Figure 1 Detailed analysis and understanding of the Pilbara has led to the identification of nine regional pillars, (from Pilbara Regional Investment Blueprint)

\section{The mine closure conundrum}

In Western Australia, the extraction of raw materials (i.e. mining and quarrying) on Crown land is facilitated by the Department of Mines, Industry Regulation and Safety (DMIRS) under either the Mining Act 1975 or the State Agreement Acts, with appropriate approvals granted by the Environment Protection Authority (EPA) and other regulatory agencies. An expectation within industry and government is that tenure will be surrendered once resource exploration and exploitation is complete. Under current legislation, mining companies are generally required to prepare mine closure plans (MCPs) in accordance with the regulatory guidance (Department of Mines and Petroleum \& Environmental Protection Authority 2015). Through this guidance, mine closure is regulated to achieve mine closure outcomes that are (physically) safe to humans and animals, (geotechnically) stable, (geochemically) non-polluting, and capable of sustaining an agreed post-mining land use. 
In addition, the guidelines require that the post-mining land use(s) that has been proposed or agreed with key stakeholders, including regulators, and that site-specific closure objectives are consistent with the agreed land use(s). Furthermore, the post-mining land use(s) must be:

- Relevant to the environment in which the mine will operate or is operating.

- Achievable in the context of post-mining land capability.

- Ecologically sustainable in the context of local and regional environment.

To assist with the determination of post-mining land use(s), the current guidelines also present the following land use hierarchy:

1. Reinstate 'natural' ecosystems to be as similar as possible to the original ecosystem.

2. Develop an alternative land use with higher beneficial uses than the pre-mining land use.

3. Reinstate the pre-mining land use.

4. Develop an alternative land use with beneficial uses other than the pre-mining land use.

While reinstatement of natural systems (i.e. restoration) may be possible for some sand and bauxite mines in the southwest region, this is possibly an unrealistic expectation for most larger metalliferous mines within the Pilbara. The fundamental alteration of the landscape and the creation of new landforms based on mining features-such as open pits, waste rock dumps (WRDs) and tailing storage dams at these mines-demand consideration of an alternative land use according to the land use hierarchy above.

Under the pressure of tight timeframes to meet market conditions, engagement with stakeholders during project approvals by mining companies is typically focused on regulatory agencies (e.g. DMIRS, EPA, Department of Water and Environmental Regulation (DWER)) rather than on regional or local planning agencies (i.e. JTSI, DPLH, DPIRD). Accordingly, land use objectives typically default to the pre-existing land use (Heyes et al. 2018). Furthermore, completion criteria for mine closure to enable tenure or obligation relinquishment are generally established around the same environmental and safety requirements that regulate the operation of the mine.

While the guidelines (Department of Mines and Petroleum \& Environmental Protection Authority 2015) encourage mining companies to explore potential land uses during MCP reviews, there is general inertia among regulators and mining companies to challenge the 'approved' land use. This is partially a result of the limitations of the Mining Act 1975 to regulate non-mining aspects of MCPs, as well as concern within mining companies that consideration of options outside of the approved land use could establish an unwanted precedent for amendment to conditions associated with legal instruments (e.g. state agreements), which impart commercial advantage (e.g. access to rail and port and power infrastructure). Some companies may also hold the view that seeking alternative land use options could be viewed as 'shirking' responsibility and that such action may damage rather than enhance the company's social licence to operate.

A further disincentive for mining companies to consider alternative land use is the fact that like mining, non-mining land uses are market driven; sustainable success is more likely where broad-scale development of multiple projects is supported by local/regional infrastructure (e.g. roads, port, rail, water, power, and natural gas services). Unlike mining, which allows private development of infrastructure, new industries are unlikely to be sustainable based on a single repurposed site. Mining companies are also miners, not developers of non-mining companies. Repurposing may therefore be seen as contrary to core business and to the objective to achieve relinquishment and a walk-away outcome.

It must also be acknowledged that there is often conflict between the agreed land use and the environmental protection objectives. The rehabilitation of areas disturbed by mining, such as overburden stockpiles and open pits, requires careful management of reactive wastes and the construction and revegetation of landforms to achieve safe and stable conditions. Typical default land uses, such as pastoralism, present a risk to such conditions as use by hooved stock can accelerate erosion and may cause eventual structural failure of rehabilitated landforms. 


\section{$4 \quad$ Emerging opportunities for mine repurposing}

Notwithstanding the mine closure conundrum, successful and sustainable achievement of alternative post-mining land use can be achieved through commercial approaches to mine closure that take advantage of ongoing human and economic occupation (Harvey 2016; Pearman 2009). Within Australia, this has been demonstrated by examples such as Genex Power's Kidston generation projects in Queensland, a company which is successfully transitioning the closed Kidston mine into hydro and solar power generation facilities, and the conversion of the Woodlawn mine in New South Wales to a landfill and bioenergy plant. Unsurprisingly, such case studies have been opportunistic and seldom involve the outgoing mining company (Butler \& Bentel 2011).

Several transformational projects within the Pilbara are now emerging or underway that demonstrate the opportunity to proactively repurpose mining assets and achieve successful outcomes for all stakeholders. While opportunities in tourism and waste management have also been identified, we have, in the interest of brevity, focused on the key opportunities of irrigated agriculture and renewables power generation for this discussion.

\subsection{Irrigated agriculture}

To meet government objectives, the then Department of Water (DoW) initiated a series of studies and policy developments (MWH 2009; Department of Water 2013; GHD 2015) that identified and prioritised 10 specific precincts based on the locations and the extent of soils potentially viable for irrigation (Figure 2). These studies were largely based on the reliance of water supply from mine dewatering operations with augmentation from groundwater. In general, sustainable yields of 6-10 gigalitres of water per year are required to establish irrigation in these precincts.

The technical viability of the irrigation precinct concept was tested by several pilot projects, including projects developed by Rio Tinto (Field \& Harold 2013) and the Woodie Bioenergy Project developed by the former Department of Agriculture and Food, now part of DPIRD, through the Royalties for Regions-funded Pilbara Hinterland Agricultural Development Initiative (PHADI).

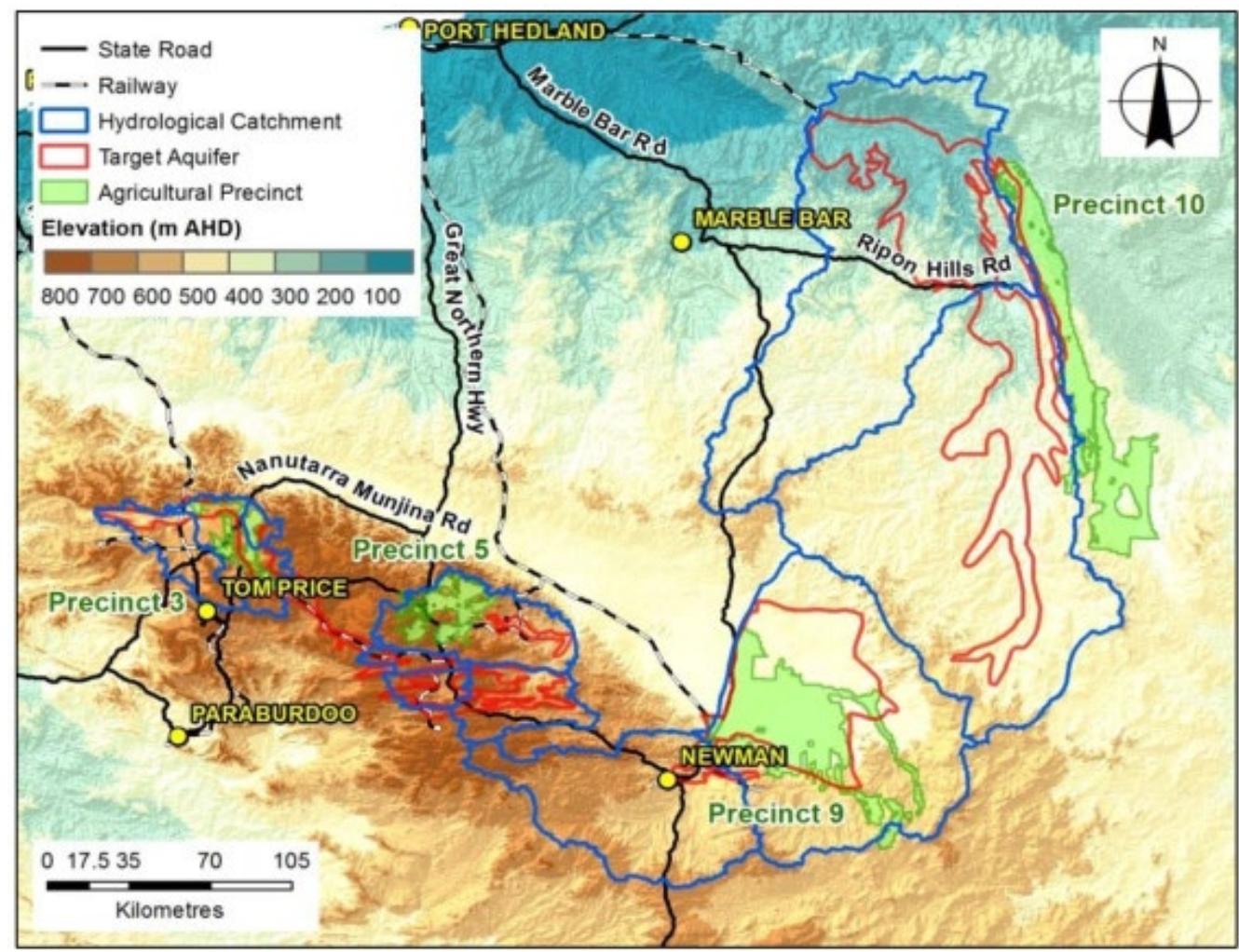

Figure 2 Preferred precincts for irrigated agriculture within Pilbara (GHD 2015) 
In response to the challenge of dependency on mine dewatering, a further study (Jacobs 2018) concluded that irrigation schemes using a mosaic model, as opposed to a more conventional expansive model, is more favourable. The study contended that conjunctive water supply-using a combination of surface water, excess mine water and groundwater supplemented by managed aquifer recharge-would provide sufficient security to support irrigated agriculture in the Pilbara. DPIRD is now progressing the assessment of market opportunities, as well as an overview of permit and tenure requirements (Department of Primary Industries and Regional Development 2017) and has announced the Transforming Agriculture in the Pilbara (TAP) project, which will invest AUD 5.9 million over three years to ground-truth soil and water resources in the region.

The potential asset value of mine voids, and specifically pit lakes, has often been raised (Johnston \& Wright 2003; McCullough \& Lund 2006; Kumar et al. 2009). The opportunity for mine voids, pit lakes and infrastructure associated with mine closure to support irrigated agriculture, however, has not yet been assessed. This is largely due to the lack of data on potential water yields and water quality constraints available post-mining (Kumar et al. 2009).

\subsection{Renewable energy production and export}

Western Australia has continued to support investment in renewable energy to achieve future energy security, deliver cleaner energy and meet long-term energy needs while facilitating economic growth and to meet the Australian Government's Renewable Energy Targets. Within the Pilbara, several renewable power generation projects are currently being considered by DPIRD (e.g. Karratha solar project), private investors and mining companies. While DPIRD projects are being driven by local demand, those being considered by mining companies are generally driven by internal company objectives for power security and greenhouse abatement and do not currently consider options for power generation beyond the life of their operations.

A recent feasibility study, funded by the Commission (Mellar et al. 2017), evaluated the potential to export photovoltaic (PV) solar power to the proposed Association of Southeast Asian Nations (ASEAN) Power Grid. The study concluded that it is technically feasible to build a competitive gigawatt scale PV solar generation and deploy subsea and overland high-voltage direct current (HVDC) transmission to deliver electricity to Indonesia. In parallel to this study, two significant renewable power generation projects are currently being considered by private investors:

- Pilbara Solar, which is part-owned by the Yamatji Marlpa Aboriginal Corporation, is seeking development funding for a pilot project from the Australian Government. The project, which has been referred to the Northern Australia Infrastructure Facility (NAIF), includes a 10-year plan commencing with building site-specific solar farms to meet mining and local demand before growing feed supply into an integrated grid across the Pilbara.

- The Asian Renewable Energy Hub is proposing to generate 9,000 MW of renewable power for both the domestic and export markets. The project is well advanced with a $14,000 \mathrm{~km}^{2}$ initial footprint proposed currently being assessed by the EPA.

Land access, site selection and environmental approvals, including vegetation clearance, are key challenges for the development of renewable power generation projects. Criteria for optimal site selection for solar generation include distance from coast $(>50 \mathrm{~km}$ but $<250 \mathrm{~km})$, site aspect and grade, proximity of infrastructure (e.g. roads) and remoteness from active mine sites and heritage areas. For wind generation, criteria also include terrain morphology and average wind speed and direction, while key criteria for pumped hydro-electric storage (PHES) include the volume of available water and the potential head between the prospective upper and lower reservoirs.

Given the above criteria, the repurposing of mining features, such as WRDs, tailings storage facilities (TSFs) and mine voids (i.e. pits), presents a unique and ready-made solution for renewable power generation and storage (i.e. pumped-hydro storage). As demonstrated by the Kidston project in Queensland, it is possible that the final landform can be engineered and designed to meet geotechnical conditions suitable for solar-array construction. 


\section{$5 \quad$ Benefits of repurposing beyond regional development}

Opportunities for economic repurposing as discussed above require an alignment with MCPs. Repurposing offers several benefits to industry, government and community alike, as discussed below.

\subsection{Improved land access, minimised clearing and reduced environmental impact}

With significant amount of land already under mining or pastoral tenure, repurposing of land from which resource development opportunities have been exhausted and which can no longer be used for pre-mining land use effectively 'releases' the pressure of land access, if that land can be made available for alternative land uses. Notwithstanding, all land uses are temporary; therefore, post-mining repurposing does not necessarily prevent future use of the land for mining should knowledge or market conditions change.

Further to improving land access, the re-use of 'disturbed' land minimises the requirement to clear undisturbed land, thereby meeting broader government objectives and protecting the environment.

\subsection{Potential mitigation of existing liabilities}

Under Section 4 of the Mining Act 1975, legal responsibility for mitigation of post-mining residual and latent impacts is not extinguished with relinquishment of mining tenure. It is well understood by the mining industry that some form of active management of residual or latent impacts, beyond monitoring, is likely to be required within the short (i.e. $<50$ years) and long-term ( $>50$ years) for most mine closures. This has led to recent consideration by many mining companies of the likelihood of long-term, and even in perpetuity, management of some sites.

Given these timeframes, it is not impossible to imagine that another land use, one which includes the management of residual and latent impacts from mining, could be established. Continued capture and treatment of contaminated groundwater or leachate from WRDs and tailings dams could be facilitated and integrated within ongoing land management practices over an extended time period, potentially mitigating residual risks to acceptable levels and negating significant costs associated with risky cover designs to prevent issues such as acid and metalliferous drainage (AMD). Funding of ongoing active impact mitigation strategies may be fully or partially supported by the mining company.

\subsection{Optimisation of costs}

Costs for land rehabilitation can reach levels nearing AUD 1 billion depending on the type of mining, residual impacts and extent of disturbance. This represents a significant investment by the mining company, as well as significant potential liability to the State, if the rehabilitation is unsuccessful. It is, therefore, not surprising that a high level of certainty regarding the outcome of closure is sought by both regulators and mining companies.

Capital investment of a non-mining land use, depending on the land use, is within a similar order of magnitude. Estimates for the installation of solar and wind generation, including land clearing and the establishment of supporting infrastructure, within the Pilbara are in the order of AUD 200-300 million for $100 \mathrm{MW}$ generation capacity.

It is, therefore, possible that the repurposing of a site could realistically optimise and reduce overall costs for both closure and development of the alternative land use, providing an attractive option for mining company and investor alike. Furthermore, potential savings could be used to cover the capital cost of additional plant or active management of residual liabilities, and/or to establish financial instruments (e.g. trusts) to cover operational cost or insurance against latent risk. 


\section{$6 \quad$ Key constraints and challenges}

Through engagement with stakeholders, several constraints and knowledge gaps have been identified that need to be addressed within the Pilbara context to support achievement of regional development objectives, provide guidance to mining companies and minimise future liabilities.

\subsection{Productive land use assessment}

As previously indicated, completion criteria to enable tenure relinquishment are generally established around the same environmental and safety requirements that regulate the operation of the mine. Examples of mine closure planning where the completion criteria have addressed future productive land and infrastructure capability are rare, if non-existent in Australia (Smyth \& Deardon 1998; Murphy \& Heyes 2016). Such land capability criteria are already being developed for agriculture in Western Australia (van Gool et al. 2005) along with guidelines for making informed decisions on land use based on land survey and land resources as broadly provided by McKenzie et al. (2008). It should, therefore, be possible to develop specific productive land use criteria for target land uses under regional development. Such criteria can be used to strengthen attempts by mining companies to assess the capability and suitability of land to support, or be engineered to support, alternative land uses. Incorporation of land use criteria with the bases of design will also align investment and closure planning processes, facilitating demonstration of potential value in repurposing as a mine closure outcome.

\subsection{Need for big data}

Such land use assessment may also be undertaken by future land users, as well as by government planning agencies. Big data on mine site characteristics, such as pit lakes and mineralised wastes, as well as residual and latent impacts, is therefore required to be made suitably available. While mining companies may be initially reluctant to provide such data, it is likely that the prospect of greater certainty of mine closure outcomes would be welcomed and supported under appropriate data access conditions. It is also likely that additional data sources, available through government departments (e.g. DMIRS, DWER, DPIRD) could be accessed and provided to support productive land use assessments.

While mining companies may undertake internal assessment of repurposing options, investors and future land users also require information about the mine sites for their own assessments. Data on mine site characteristics would therefore need to be collated and made available. The Index of Biodiversity Surveys for Assessments (IBSA)-recently launched by the EPA, DWER and DMIRS in conjunction with the Western Australian Biodiversity Science Institute (WABSI) - is an example of a similar project to capture, and make publicly available, biodiversity data that could be adopted for mine repurposing outcomes.

\subsection{Collaborative engagement among stakeholders}

A key element of multiple and sequential land use outcomes is provision of strong early leadership from government, industry and the community with articulation of the broad areas of responsibilities in terms of facilitating and leading the required changes (Standing Council on Energy \& Resources 2013). Critical to this leadership is establishing an appropriate forum in which stakeholders, including the community and future investors, can be encouraged to present their ideas and engage directly with both government and mining companies. This may include a regular or periodic forum, or a formal 'office' within government, such as recently seen in Victoria with the establishment of a rehabilitation commissioner for implementation of the Latrobe Valley Regional Rehabilitation Strategy (LVRRS).

\subsection{Liability models}

As indicated above, the active management costs of residual and latent impacts may be borne through commercial arrangement between the outgoing mining company and the incoming land user. Potential financial mechanisms and instruments for the ongoing management of a closed mine are presented by 
Bocking \& Fitzgerald (2012) and Mackenzie (2016). Such mechanisms and instruments must be sustainable and independent of the mining company and preferably incorporated into standard land management practices supporting future land use (Murphy \& Heyes 2016). However, it will be necessary for such mechanisms to be assessed and tested in both the Western Australian and Pilbara context.

\section{$7 \quad$ Framework for mine repurposing}

Opportunities for future development of irrigated agriculture within the Western Australian Rangelands are being supported by the Western Australian Government's Water for Food program and funded by investment through Royalties for Regions. A significant constraint on the realisation of the State's ability to harness this potential has been the restriction on land use and specifically the repurposing of land use created by the Land Administration Act 1997. In response to this challenge, the DPLH has established the Land Tenure Pathway for Irrigated Agriculture (LTPIA) to facilitate the repurposing of pastoral land use for irrigated agriculture (Department of Lands 2016). Several proposals are now moving through the LTPIA process for irrigated development in the Kimberley region.

While limited guidance currently exists for relinquishment of mining tenure under the Mining Act 1975, this fundamentally requires demonstration to DMIRS that the objectives of a safe, stable and non-polluting landscape have been met and that this is compatible with the agreed post-mining land use. Irrespective of mine tenure relinquishment, an application for the use of the underlying land for alternative use must be made through the Land Administration Act 1997. Depending on the existing tenure under the Act, such application must be made under the LTPIA (for pastoral land) or a general application (for other land, including unallocated Crown land). In theory, it is possible for land to be repurposed under the Land Administration Act, even if mining tenure under the Mining Act exists.

\subsection{Existing mines}

The draft framework to facilitate the repurposing of mine sites in Western Australia has focused on existing mines and mimics the LTPIA process. It includes the orderly demonstration of compliance with agreed completion criteria under the Mining Act. Such compliance may well incorporate demonstration that the post-mining land use is capable of mitigating residual and latent impacts from mining under appropriate commercial arrangements.

While strategic activities undertaken by regional forums and facilitated through DPIRD-and specifically the Commission - will be needed, the more tactical aspects of bridging land tenure and legislative gaps will need to be dealt with by the DPLH through an LTPMR. To accommodate countercurrent proposals for project development and mine tenure relinquishment, the LTPMR would require close involvement with, and by, DMIRS for mining tenure and the JTSI for State Agreement Acts. An indicative LTPMR process, presenting potential activities and key steps, is provided in Figure 3. For the purposes of the indicative process, it has been assumed that the outgoing mining company and incoming investor/developer would act as joint proponents and that interdependent and parallel processes within the DPLH and DMIRS/JTSI would need to apply.

While government stakeholders have indicated a willingness to consider proposals presented by proponents for repurposing, there is some nervousness within industry stakeholders regarding the initiation of the process and the potential constructive obligation and expectation created within community stakeholders. Uncertainty regarding the ability to transfer or manage liability and the risk of precedent were also raised as key concerns.

The specific detail of the LTPMR will need to be supported by the current guidelines for relinquishment being developed by DMIRS as well as the proposed revision of the Guidelines for Preparing Mine Closure Plans (Department of Mines and Petroleum \& Environmental Protection Authority 2015). Based on the current LTPIR process (Department of Lands 2016), it is likely that timeframes for the LTPMR process would be between four and six years, depending on the level of understanding confidence regarding residual and latent liabilities.

In all discussions, the difficulty in identifying and bringing potential future land users and investors to the table has been raised. Ideally, the demand for land would drive the investigation and engagement of 
investors; however, there is a current perception that post-mining land is off limits. Potential to shift this inertia through either an expression of interest process or the use of specialised land brokerage companies, or even a 'hackathon', have been raised by stakeholders. The potential role of these mechanisms is being explored in ongoing discussions.

While the process may seem daunting, it does not differ greatly from the existing project development and approval processes with Western Australia. It does, however, provide clarity on how to navigate the necessary cross-statute approvals and support a whole-of-government approach to address the challenges of mine closure.

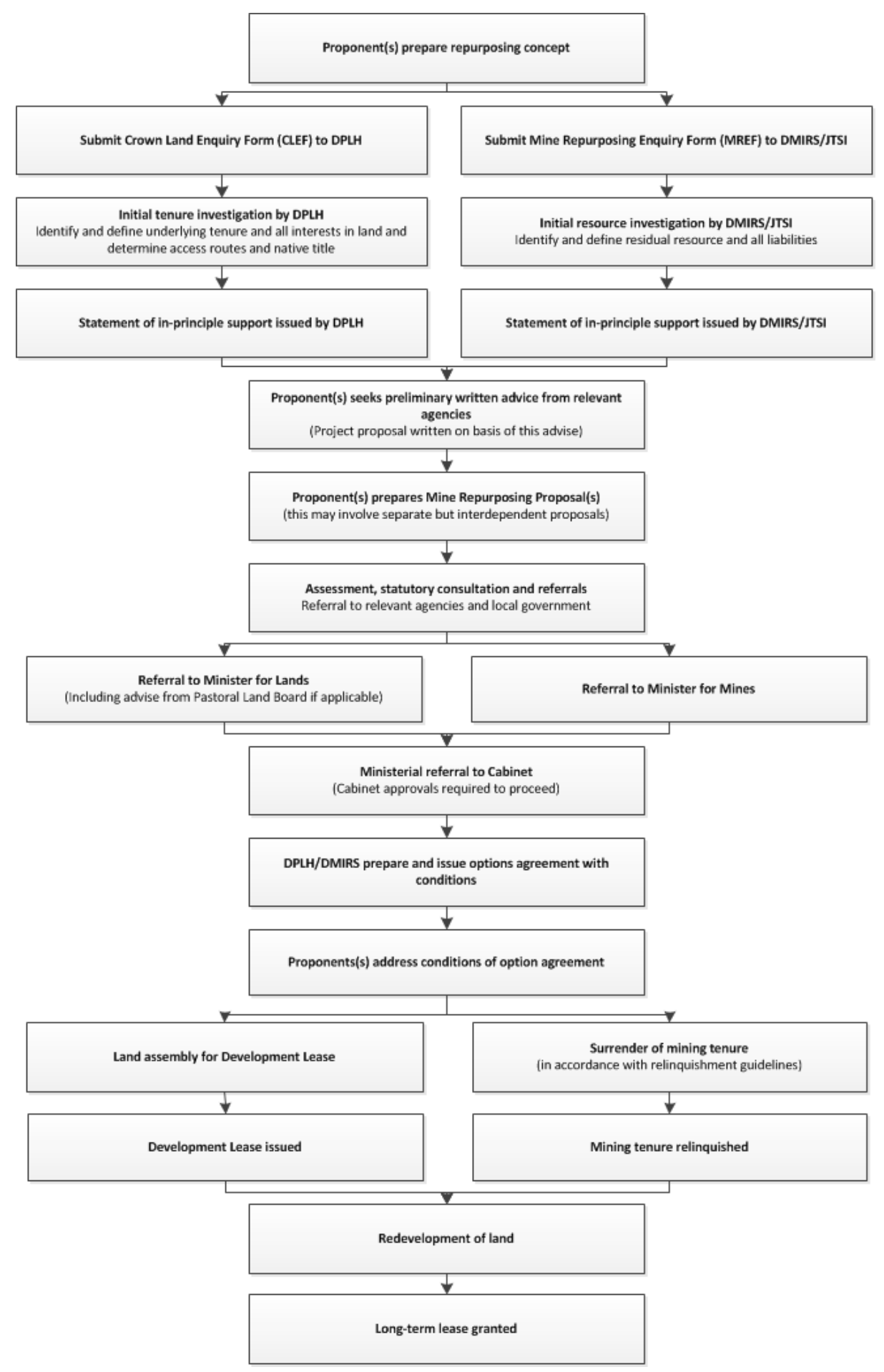

Figure 3 Indicative Land Tenure Pathway for Mine Repurposing (adapted from Department of Lands 2016) 


\subsection{New mines}

It is recognised that the process for considering repurposing for new mines presents temporal and even intergenerational challenges with respect to final land use on mines that may operate for 30 or more years. It is possible that in some circumstances progressive repurposing may be possible, similar to the current concept or progressive rehabilitation. This obviously introduces additional complexity and requires a level of comfort from all stakeholders in the process. Ongoing discussions with stakeholders through the MIRI are starting to tease out the challenges and issues associated with how repurposing may be considered within mine planning and development, including the appropriateness of specific conditions being applied to mining tenure for consideration of productive land use outcomes.

\section{Discussion and conclusion}

The successful execution of mine closure planning is an emerging issue across Australia. Current regulatory frameworks have had limited success in facilitating and enabling sustainable economic and environmental outcomes. This can largely be attributed to risk averse laws and a focus on passive environmental protection and restoration. To date, there has been limited consideration from either industry or government of active, productivity-focused outcomes based on sustainable development principles that acknowledge and accept residual and latent impact associated with mining as a temporary land use.

Specific development opportunities associated with irrigated agriculture and renewable power generation are already advanced within the Pilbara region. This includes the development of a gigawatt scale power generation network feeding the ASEAN and the North West Interconnected System (NWIS) grids, as well as the development of one or more agriculture precincts to realise local and potential export demand for high-value crops. These opportunities are aligned with the Pilbara Blueprint (Pilbara Development Commission 2015) and are gaining support and interest across both government and industry. Proposed development, however, is constrained by land access and environmental protection potentially resulting in suboptimal outcomes. Repurposing of mine sites, therefore, offers significant opportunity to optimise development of irrigated agriculture and renewable power generation projects.

Despite existing constraints, all the elements of a robust and efficient legal and policy framework for repurposing of mine sites within Western Australia already exist. Such a framework, based on the LTPIA (Department of Lands 2016), has the potential to align with current regional development strategies, reduce potential liabilities from closed mines falling to the State, as well as provide mining companies with a clear and certain avenue to repurpose their assets and leave a positive legacy for future generations. The introduction of investors looking to develop future productive land uses provides the opportunity for both the management of residual and latent liabilities, as well as ongoing economic development, to achieve sustainable social, environmental and economic outcomes.

A shift in the paradigm of mine closure will require a whole-of-government approach to facilitate the bringing together the multitude of current agendas-including approval policy reform, land access, environmental protection, mine closure and regional development - to achieve truly sustainable development outcomes. Fundamental to this shift is recognition that all land uses are temporary and sequential land use is critical to address land access and environmental protection challenges. The currently prohibitive views regarding acceptance of risk and transfer of assets and liabilities must be challenged to enable identification and development of repurposing projects that can achieve the certainty desired by all parties. This must also include the early and open engagement of future investors within the planning process.

Mining companies will similarly need to demonstrate leadership to break down current views on liability and asset transfer to achieve sustainable mine closure outcomes and leave positive legacies within host communities that contribute to and enhance their social license to operate. They must also actively address knowledge gaps and be prepared to embrace closure as core business to achieve objectives and certainty of socio-economic outcomes. 
Not every mine site presents a repurposing opportunity, and sustainable repurposing is not always supported by a single mine. Successful reduction of potential future liabilities, through mine site repurposing, must incorporate a regional perspective and seek to guide common mine closure outcomes across multiple mines to achieve sustainable future land use and industry. This will require the development of regional-scale strategies and the formation of collaborative forums in which specific opportunities can be identified, explored, tested and ultimately adopted.

While mine repurposing is occurring globally, such projects are generally ad hoc and are driven by opportunistic investors and innovative communities, rather than by proactive strategy or policy. It is proposed, however, that Western Australia can capitalise on existing policy reform and planning activities to develop a coordinated framework for the identification, facilitation and optimisation of land use and mine repurposing. This has the potential to place the State in a globally leading position in mine closure, mine site repurposing, regional development and environmental management.

To break the ice on mine site repurposing, there is a need to explore specific opportunities without the expectation of commitment from any party beyond initial concept studies. Such studies must investigate the social, economic and environmental dimensions of the repurposing opportunity, including tenure, licensing, liability transfer and funding. Comparison to 'greenfields' development, to clearly demonstrate the benefits offered by repurposing, will also need consideration. Key criteria for comparison would be expected to include, but not necessarily limited to, project development and approval timeframes, mitigation of risk, economic impact and sustainability of outcome.

\section{Acknowledgement}

Numerous representatives of mining companies, government agencies, peak industry bodies and future land users have been engaged and consulted during the Mines and Infrastructure Repurposing Initiative. All those who have given their time to discuss the many perspectives of mine repurposing are sincerely thanked.

\section{References}

Australian Bureau of Statistics 2013, A Review of Regional Development Australia Committee Regional Plans, viewed 24 July 2016 , http://www.abs.gov.au/ausstats/abs@.nsf/mf/1381.0

Butler, H \& Bentel, GM 2011, 'Mine relinquishment - process and learnings', in AB Fourie, M Tibbett \& A Beersing (eds), Proceedings of the Sixth International Conference on Mine Closure, vol. 2, Australian Centre for Geomechanics, Perth, pp. 3-11.

Bocking, KA \& Fitzgerald, P 2012, 'Management and financing of post-closure liabilities', in AB Fourie \& M Tibbett (eds), Proceedings of the Seventh International Conference on Mine Closure, Australian Centre for Geomechanics, Perth, pp. 49-56.

Commonwealth of Australia 2019, Rehabilitation of Mining and Resources Projects and Power Station Ash Dams as it Relates to Commonwealth Responsibilities, Environment and Communications References Committee, Canberra, viewed 24 March 2109, https://www.aph.gov.au/Parliamentary_Business/Committees/Senate/Environment_and_Communications/MiningandResources /Report

Department of Lands 2016, Land Tenure Pathway for Irrigated Agriculture - Application Guidelines, viewed 9 July 2019, https://www.agric.wa.gov.au/sites/gateway/files/LTPIA\%20Application\%20Guidelines.pdf

Department of Mines and Petroleum \& Environmental Protection Authority 2015, Guidelines for the Preparation of Mine Closure Plans, Perth, viewed 15 August 2015, http://www.dmp.wa.gov.au/Documents/Environment/ENV-MEB-121.pdf

Department of Primary Industries and Regional Development 2017, Growing the Pilbara: A Prefeasibility Assessment of the Potential for Irrigated Agriculture Development, viewed 23 August 2018, https://www.agric.wa.gov.au/sites/gateway/files/ DPIRD_Growing\%20the\%20Pilbara.pdf

Department of Water 2013, Strategic Policy 2.09: Use of Mine Dewatering Surplus, Perth, viewed 24 August 2018 , https://www.water.wa.gov.au/_data/assets/pdf_file/0018/1683/105196.pdf

Field, G \& Harold, M 2013, Development of Beneficial use Solutions for Surplus Water from Marandoo Mine: Lessons learned, viewed 12 March 2017, http://www.globalgw.com.au/references/OzWater_2013_GField_MHarold_Final.pdf

GHD 2015, Economic Analysis of Irrigated Agriculture Development Options for the Pilbara, viewed 24 August 20198, https://www.agric.wa.gov.au/irrigated-crops/economic-analysis-irrigated-agriculture-development-options-pilbara

Harvey, BE 2016, 'The Eye of the Beholder - Utility and Beauty in Mine Closure', in AB Fourie \& M Tibbett (eds), Proceedings of the 11th International Conference on Mine Closure, Australia Centre for Geomechanics, Perth, pp. 17-24.

Heyes, J, Murphy, D, Foster, S \& White, S 2018, 'What comes after mining? How regulatory frameworks can enable creativity', in C Drebenstedt, F von Bismark, AB Fourie \& M Tibbett (eds), Proceedings of the 11th International Conference on Mine Closure, Technical University Bergakademie Freiberg, Freiberg, pp. 173-182. 
Jacobs 2018, Pilbara Irrigated Agriculture Feasibility Study: Preliminary Business Case for Investment, viewed 24 August 2018, https://www.agric.wa.gov.au/r4r/irrigation-pilbara?page $=0 \% 2 \mathrm{C} 1$

Johnston, SL \& Wright, AH 2003, Mine Void Water Resource Issues in Western Australia, Water and Rivers Commission Hydrogeological Record Series Report No. HG 9, viewed 12 March 2017, http://www.dmp.wa.gov.au/Documents/Minerals/mineralsminerals_guidelines_and_environmental_notes-mine_void_water_resources.pdf

Kumar, RN, McCullough, CD \& Lund, MA 2009, 'Water resources in Australian mine pit lakes', Proceedings of Water in Mining 2009, The Australasian Institute of Mining and Metallurgy, Melbourne.

Lock the Gate 2016a, Mine Rehabilitation and Closure Cost: A Hidden Business Risk, viewed 24 July 2016, http://www.lockthegate.org.au/mine_rehabilitation_and_closure

Lock the Gate 2016b, Rhetoric vs Reality: A Snap Shot of Progressive Rehabilitation Performance in the Global Mining Industry, viewed 24 July 2016, https://d3n8a8pro7vhmx.cloudfront.net/lockthegate/pages/3277/attachments/original/1479686290/FINAL_ FINAL_Rhetoric_vs_Reality___a_performance_snap_shot_AD_25_Jul.pdf?1479686290

Mackenzie, S 2016, 'Post-closure funding initiatives to facilitate custodial transfer and relinquishment of mining tenure', in AB Fourie \& M Tibbett (eds), Proceedings of the 11th International Conference on Mine Closure, Australian Centre for Geomechanics, Perth, pp. 419-422.

McKenzie, NJ, Grundy, MJ, Webster, R \& Ringrose-Voase, AJ 2008, Guidelines for Surveying Soil and Land Resources, 2nd edn, CSIRO Publishing, Melbourne.

McCollough, CD \& Lund, MA 2006, 'Opportunities for sustainable mining pit lakes in Australia', Mine Water and the Environment, vol. 25 , iss. 4 , pp. 220-226.

Mellar, S, James, G \& Chalmers, K 2017, Pre-feasibility Study: Evaluating the Potential to Export Pilbara Solar Resources to the Proposed ASEAN Grid via a Subsea High Voltage Direct Current Interconnector, Report to Pilbara Development Commission, viewed March 12 2018, http://www.pdc.wa.gov.au/our-focus/pilbara-blueprint/pilbarasolar

Murphy, D \& Heyes, J 2016, 'Mine closure - are we using the right drivers?', AusIMM Bulletin, October 2016, viewed 12 March 2017, https://www.ausimmbulletin.com/feature/mine-closure-are-we-using-the-right-drivers/

MWH 2009, Pilbara Integrated Water Supply Pre-Feasibility Study, Perth, viewed 24 August 2018, https://www.mediastatements.wa.gov.au/MediaDocuments/PilbaraPre\%E2\%80\%93FeasabilityStudy.pdf

Pilbara Development Commission 2015, Pilbara Regional Investment Blueprint, Perth, viewed 24 July 2016, https://www.pdc.wa.gov.au/our-focus/pilbara-blueprint

Pearman, G 2009, 101 Things to do with a Hole in the Ground, Post-Mining Alliance, Cornwall.

Roche, C \& Judd, S 2016, Ground Truths: Taking Responsibility for Australia's Mining Legacies, Mineral Policy Institute, Girrawheen, viewed 24 July 2016, http://www.mpi.org.au/wp-content/uploads/2016/06/Ground-Truths-2016-web.pdf

Standing Council on Energy and Resources 2013, Multiple Land Use Framework, viewed 12 March 2014 , http://www.coagenergycouncil.gov.au/publications/multiple-land-use-framework-december-2013

Smyth, CR \& Dearden, P 1998, 'Performance standards and monitoring requirements of surface coal mine reclamation success in mountainous jurisdictions of western North America: a review', Journal of Environmental Management, vol. 53, pp. 209-229.

Tomaney, J 2010, Place-based Approaches to Regional Development: Global Trends and Australian Implications, Australian Business Foundation, viewed 18 August 2018, http://groupedebruges.eu/sites/default/files/publications/downloads/tomaney_2010_ place-based_approaches to regional_development.pdf

van Gool, D, Tille, P \& Moore, G 2005, Land Evaluation Standards for Land Resource Mapping, Resource Management Technical Report 298 3rd Ed, Department of Agriculture, viewed 12 March 2017, https://researchlibrary.agric.wa.gov.au/rmtr/280/ 
